\title{
PENGEMBANGAN MODUL PEMBELAJARAN FISIKA BERBASIS METAKOGNISI DI KELAS XI IPA SMA NEGERI 1 SUNGGAL
}

\author{
Muhammad Isnaini ${ }^{1}$, R. Mursid ${ }^{2}$ \\ Teknologi Pendidikan Program Pascasarjana Universitas Negeri Medan \\ isnain2.0407@gmail.com¹, mursid.tp@gmail.com²
}

\begin{abstract}
Abstrak: Penelitian dan pengembangan ini bertujuan untuk: (1) menghasilkan modul pembelajaran fisika berbasis metakognisi yang layak digunakan dan mudah untuk dipelajari, dan (2) mengetahui tanggapan siswa terhadap modul pembelajaran fisika berbasis metakognisi yang telah dihasilkan. Jenis penelitian ini adalah penelitian pengembangan yang menggunakan model pengembangan produk Borg dan Gall yang dipadu dengan model pengembangan pembelajaran Dick dan Carey. Model pengembangan produk disusun secara terprogram dengan urutan yang sistematis dan memenuhi karakteristik siswa dalam belajar meliputi tiga tahapan, yakni studi pendahuluan, perencanaan dan penyusunan modul serta ujicoba modul. Subyek uji coba terdiri dari dua ahli materi pelajaran Fisika, satu ahli desain pembelajaran, dua ahli media pembelajaran, tiga siswa untuk uji perorangan, sembilan siswa untuk uji kelompok kecil, dan tiga puluh empat siswa untuk uji lapangan. Data tentang kualitas produk pengembangan ini dikumpulkan dengan angket. Data-data yang dikumpulkan dianalisis dengan teknik analisis deskriptif kualitatif. Hasil penelitian menunjukkan; (1) uji ahli materi pelajaran Fisika berada pada kriteria sangat baik dan layak digunakan, (2) uji ahli desain pembelajaran berada pada kriteria sangat baik dan layak digunakan, (3) uji ahli media pembelajaran berada pada kriteria sangat baik dan layak digunakan, (4) uji coba perorangan berada pada kriteria sangat baik, uji coba kelompok kecil berada pada kriteria sangat baik, dan uji coba lapangan berada pada kriteria sangat baik.
\end{abstract}

\section{Kata Kunci: modul pembelajaran fisika berbasis metakognisi}

\begin{abstract}
The research and development is aimed at: (1) produce a physics-based learning modules metacognition proper use and easy to learn, and (2) determine the response of students to the physics-based learning modules metacognition that has been generated. This type of research is the development of research that uses models Borg and Gall product development combined with learning development model of Dick and Carey. Product development model prepared programmatically using a systematic order and meet the characteristics of the students in learning includes three stages, ie preliminary studies, planning and preparation of modules and module testing. The subject of the trial consists of two subject matter experts in Physics, an instructional design specialist, two instructional media experts, three students for individual trials, nine students for small group test, and thirty-four students for field testing. Data about the quality of the products of this development are collected by questionnaire. The data collected were analyzed using qualitative descriptive analysis techniques. The results showed; (1) The test of subject matter experts Physics currently on the criteria very well and fit for use, (2) test expert instructional design currently on the criteria very well and fit for use, (3) test expert instructional media that are in very good criteria and fit for use, (4) individual testing criteria are very good, small group trial was on the criteria very well, and field trials are in very good criteria.
\end{abstract}

Keywords: physics-based learning modules metacognition

\section{PENDAHULUAN}

Keberhasilan seorang siswa dalam menyelesaikan tugas fisika dapat bergantung pada kesadarannya tentang apa yang ia ketahui dan bagaimana ia menerapkannya atau bermetakognisi. Dapat juga dijelaskan bahwa metakognisi adalah suatu kata yang berkaitan dengan apa yang dia ketahui sebagai individu yang belajar dan bagaimana dia mengontrol serta menyesuaikan perilakunya.

Anderson \& Krathwohl (2001) merevisi Taksonomi Bloom tentang aspek kognitif 
menjadi dua dimensi, yaitu: 1) dimensi proses kognitif dan 2) dimensi pengetahuan. Hasil revisi yang menonjol tentang dimensi proses kognitif adalah ditiadakannya aspek sintesis di antara aspek analisis dengan aspek evaluasi serta ditambahkannya aspek kreativitas sesudah aspek evaluasi. Sedangkan aspek-aspek dari dimensi pengetahuan yang dikemukakan adalah: (1) pengetahuan faktual (factual knowledge), (2) pengetahuan konseptual (conceptual knowledge), (3) pengetahuan prosedural (procedural knowledge), dan (4) pengetahuan metakognitif (metacognitive knowledge).

Anderson \& Kathwohl (2001) memasukkan metakognisi dalam high-level proses kognitif yang merupakan tujuan akhir dari pembelajaran. Tujuan akhir dari pembelajaran adalah menyampaikan pengetehuan, meningkatkan kemampuan siswa untuk merencanakan dan memonitor, bahkan mereorganisasi strategi pembelajarannya sendiri (Shen \& Liu, 2011:140). Dengan kata lain, tujuan pembelajaran adalah menciptakan manusia yang kreatif, mandiri, mampu menyusun konsep dan pengetahuannya sendiri. Hal ini sesuai dengan tujuan pendidikan nasional dalam Undang-undang Republik Indonesia Nomor 20 Tahun 2003 yang menyatakan bahwa pendidikan nasional bertujuan untuk mengembangkan potensi siswa agar menjadi manusia yang beriman dan bertakwa kepada Tuhan Yang Maha Esa, berakhlak mulia, sehat, berilmu, cakap, kreatif, mandiri dan menjadi warga Negara yang demokratis serta bertanggung jawab. Pentingnya metakognisi dalam pembelajaran didukung pula dengan Permendiknas Nomor 41 Tahun 2007 tentang standar proses yang menyatakan bahwa dalam kegiatan pembelajaran, guru memberikan kesempatan kepada siswa untuk dapat memahami, merancang, memecahkan masalah, mengetahui bagaimana cara dan mengapa melakukan hal tersebut, menganalisis, memonitor, mengevaluasi dan mengembangkan pemahaman konsepnya. Seluruh rangkaian kegiatan di atas merupakan bagian dari metakognisi.

Sejak tahun 2000, pendidikan fisika berfokus bagaimana proses siswa mengkonstruksi pengetahuan yang dimilikinya (Rebello \& Zollman, 2005:8). Salah satu faktor yang kosntruksi pengetahuan adalah metakognisi. Metakognisis diakui merupakan salah satu variabel yang penting untuk pembelajaran (Dosoete, 2007:708). Kemampuan metakognisi dapat meningkatkan kapasitas belajar yang penuh makna, membentuk serta mempengaruhi kosntruksi pemahaman siswa (Anderson \& Nashon, 2006:299). Berdasarkan pengkajian terhadap 179 penelitian tentang prestasi belajar, Shen \& Lui (2001:140) mengemukakan bahwa metakognisi menduduki peringkat pertama dari 200 faktor yang mempengaruhi hasil pendidikan. Mereka menunjukkan bahwa metakognisi adalah kemampuan untuk mengaitkan pesan penting dengan pengetahuan sebelumnya, menarik kesimpulan dan memantau atau menilai kinerja pribadi yang ditunjukkan ketika proses belajar. Selain itu, pembelajaran berbasis metakognisi membantu penyelesaian masalah secara efektif dan membantu konsep yang tepat (Georghiades, 2000:127)

Seiring dengan pekembangan psikologi kognitif, maka berkembang pula cara guru dalam mengevaluasi pencapaian hasil belajar, terutama untuk domain kognitif. Akan tetapi, saat ini dalam mengevaluasi pencapaian hasil belajar, guru hanya memeberikan penekanan pada tutujuan kognitif tanpa memperhatikan dimensi proses kognitif, khususnya pengetahuan dan pengalaman metakognitif (Mulbar, 2008:2). Akibatnya pembelajaran di kelas terfokus pada penguasaan kognisi siswa dan cenderung mengabaikan upaya-upaya memperkenalkan metakognisi kepada siswa. Padahal, kemampuan metakognisi sangat penting untuk proses belajar siswa terutama dalam pembelajaran fisika.

Fisika merupakan sains atau ilmu pengetahuan paling fundamental karena merupakan dasar dari semua bidang sains. Fisika berhubungan dengan materi dan energy, hukumhukum yang mengatur gerakan partikel dan gelombang, interaksi antar partakel, sifat-sifat molekul, atom dan inti serta sistem-sistem berskala lebih besar seperti gas, cair, dan padat. Akan tetapi, fisika dianggap sebagai salah satu mata pelajaran yang sulit oleh sebagian besar siswa. Hal ini dikarenakan fisika membutuhkan matematika yang rumit (Nason dalam Campbell, 2007:3), materi yang terlalu banyak, bergantung pada buku teks, abstrak dan komplek (Sheppard dan Robin dalam Campbell, 2007:4), membutuhkan kegiatan labolatorium dan sering menjadi miskonsepsi (Heller \& Heller, 1999:12)

Berdasarkan karaktristik fisika, belajar bukan hanya mencari jalan penyelesaian dari persamaan, tetap juga belajar mendeskripsikan, 
belajar tentang suatu fenomena dan memahami system fisika. Siswa membutuhkan kognisi yang lebih dari sekedar kognisi. Mereka membutuhkan pengetahuan tentang apa yang diketahui dan tidak diketahui, bagaimana memecahkan masalah, membuan perencanaan pemecahan masalah, membuat pemecahan masalah dengan cara yang ditempuhnya, memonitor proses belajar dan kemajuannya ke arah tujuan saat melaksanakan rencana serta mengevaluasi apa yang sudah dilakukan (Gok, 2010:116). Proses-proses tersebut merupakan proses metakognisi. Kipnis dan Hofstein dalam Simanjuntak (2011:10) menyatakan pada pembelajaran sains ditemukan bahwa prosesproses metakognisi memberikan pelajaran yang penuh arti atau belajar dengan mengembangkan pemahaman.

Menurut hasil pengamatan yang dilakukan peneliti melalui observasi kelas dan wawancara dengan guru mata pelajaran fisika SMA Negeri 1 Sunggal menunjukkan bahwa kebanyakan siswa hanya menunggu instruksi dari guru, hal ini disebabkan: (1) siswa tidak memiliki budaya belajar mandiri, selalu bergantung pada guru, tanpa diterangkan guru siswa tidak mau belajar sendiri, (2) siswa cenderung kurang aktif dalam proses pembelajaran, (3) kurangnya sumber belajar sehingga siswa tidak memiliki kesempatan untuk mengetahui lebih dahulu materi yang akan dibahas, (4) sebagian besar siswa belum mampu menghubungkan materi yang dipelajari dengan pengetahuan yang digunakan atau dimanfaatkan, (5) berdasarkan nilai UTS mata pelajaran Fisika tahun ajaran 2013/2014, sekitar 30\% siswa kelas XI IPA belum mencapai nilai KKM (Kriteria Ketuntasan Minimal) sebesar 7.

Menurut guru, metakognisi merupakan hal yang sulit untuk diakses meskipun diakui sangat penting keberadaannya. Hal ini disebabkan karena tuntutan yang diberikan kepada guru agar mampu membawa semua siswa mencapai target ketuntasan materi fisika, sedang waktu/kegiatan tatap muka di dalam kelas terbatas. Sehingga, fokus kegiatan pembelajaran seringkali didominasi oleh penyampaian informasi sebanyak-banyaknya tanpa memberikan kesempatan kepada siswa untuk mengkonstruksi pengetahuannya sendiri. Joyce \& Marsha (1996:51) menyebutkan bahwa dalam metakognisi ada proses "letting the student in on the secret" sehingga siswa dapat membangun sendiri pengetahuan dan kemampuan mereka, memutuskan strategi belajar apa yang akan digunakan, pemecahan masalah dan menemukan sendiri ilmu yang akan dipelajari.

Berdasarkan analisis berbagai permasalahan di atas, guru dan siswa di SMA Negeri 1 Sunggal membutuhkan media pembelajaran berbasis metakognisi untuk mengatasi keterbatasan penerapan metakognisi dalam kegiatan pembelajaran. Media belajar tersebut harus mampu digunakan secara mandiri oleh siswa sehingga tanpa guru pun mereka dapat melakukan kegiatan belajar sendiri. Sehingga siswa dapat melakukan kegiatan belajar kapanpun dan dimanapun dengan mengaktifkan metakognisinya. Dengan demikian, intensitas penggunaan metakognisi akan meningkat dan teraktifkan setiap kali siswa melaksanakan kegiatan belajar.

Oleh karena itu, pengembangan modul merupakan salah satu media yang sesuai mendukung pembelajaran fisika karena perlu adanya buku panduan yang mempermudah pemahaman siswa dalam mempelajari materi. Modul merupakan bahan ajar berbentuk media cetak yang dirancang untuk dipelajari sendiri oleh siswa. Modul disebut juga media untuk belajar mandiri karena di dalamnya telah dilengkapi petunjuk untuk belajar sendiri. Artinya, pembaca dapat melakukan kegiatan pembelajaran tanpa kehadiran pengajar secara langsung (Dharma, 2008:3). Modul berbasis metakognisi dapat digunakan sebagai alternatif media belajar berbasis metakognisi yang mampu mengatasi keterbatasan ruang dan waktu belajar. Akan tetapi, guru di SMA Negeri 1 Sunggal belum pernah mengembangkan modul fisika berbasis metakognisi.

Perubahan tingkah laku seperti pemahaman konsep dan kecakapan baru, serta pembentukan sikap dari perbuatan atau tingkah laku positif disebabkan adanya pertambahan pengalaman atau pengetahuan yang diperoleh setelah proses belajar. Jadi ada nilai tambah dari pengalaman yang dimiliki sebelumnya. Munadi (2013:21) mengatakan setiap teori belajar dirumuskan berdasarkan kajian tentang perilaku individu dalam proses belajar. Kajian itu pada intinya menyangkut dua hal: (1) konsep yang menggap bahwa otak terdiri atas sejumlah kemampuan potensial seperti menalar, mengingat dan menghayal yang dapat dikembangkan dengan latihan, (2) konsep yang menganggap bahwa manusia merupakan suatu 
system energy yakni suatu system tenaga dinamis yang berupaya memelihara keseimbangan dalam merespon sistem energy sehingga ia dapat berinteraksi melalui organ rasa. Sistem energy ini meliputi respon terhadap stimulus, motivasi, dan proses penalaran.

Belajar adalah suatu proses yang dilakukan seseorang untuk memperoleh suatu perubahan tingkah laku yang baru secara keseluruhan, sebagai hasil pengalamannya sendiri dalam interaksi dengan lingkunganya (Slameto, 2010:2). Belajar dapat didefinisikan sebagai proses dimana suatu organisme berubah perilakunya sebagai akibat dari pengalaman. Belajar juga merupakan syarat mutlak untuk menjadi pandai dalam segala hal, baik dalam bidang ilmu pengetahuan maupun keterampilan atau kecakapan.

Fisika adalah bidang ilmu yang banyak membahas tentang alam dan gejalanya, dari yang bersifat riil (terlihat secara nyata) hingga yang bersifat abstrak atau bahkan hanya berbentuk teori yang pembahasannya melibatkan kemampuan imajinasi atau keterlibatan gambaran mental yang kuat (Setiawan, 2012:285). Tujuan pembelajaran fisika di sekolah menengah secara umum adalah memberikan bekal pengetahuan tentang fisika, kemampuan dalam keterampilan proses, serta meningkatkan kreativitas dan sikap ilmiah. Berdasarkan tujuan tersebut, diperlukan pembelajaran yang tepat dalam mengajarkan fisika di sekolah agar siswa dapat memahami konsep fisika secara mendasar sehingga tujuan pembelajaran fisika tercapai.

Pembelajaran fisika adalah salah satu bentuk pelaksanaan pendidikan fisika di sekolah. Dalam pembelajaran fisika terdapat kegiatan penyadaran atau penguasaan fisika pada siswa melalui interaksi pengajaran atau proses belajar mengajar (Sutarto, 2005 dalam Setiawan, 2012:286). Proses pembelajaran fisika menekankan pada pemberian pengalaman langsung untuk mengembangkan kompetensi agar menjelajahi dan memahami alam sekitar secara ilmiah. Pelaksanaan kegiatan inti merupakan proses pembelajaran untuk mencapai Kompetensi Dasar (KD) yang dilakukan secara interaktif, inspiratif, menyenangkan, menantang, dan memotivasi peserta didik untuk berpartisipasi aktif, serta memberikan ruang yang cukup bagi prakarsa, kreativitas, dan kemandirian sesuai dengan bakat, minat dan perkembangan fisik serta psikologis peserta didik. Oleh karena itu, pembelajaran fisika di sekolah menengah harus menekankan pada aktivitas siswa.

Berdasarkan dimensi pengetahuan dan proses kognitif, menurut Krathwohl (2002:214), selain terdapat tiga kategori pengetahuan, yaitu pengetahuan factual, pengetahuan konseptual, pengetahuan prosedural, ditambahkan kategori yang keempat yaitu pengetahuan metakognitif.

Secara harfiah, metakognisi bisa diterjemahkan secara bebas sebagai kesadaran berfikir tentang apa yang dipikirkan dan bagaimana proses berpikirnya, yaitu aktivitas individu untuk memikirkan kembali apa yang telah terpikir serta berpikir dampak sebagai akibat dari buah pikiran terdahulu. John Hurley Flavell pertama kali menggunakan istilah kata "metakognisi" yang merujuk pada pengetahuan seseorang tentang proses kognisi sendiri atau segala sesuatu yang berhubungan dengan ranah kognisi, misalnya, belajar sesuatu yang relevan dari informasi atau data. Metakognisi mengacu pada control yang benar-benar sadar akan aktivitas kognisinya (Brown, 1980). Favell dalam Gama (2004) menyatakan bahwa pengetahuan metakognitif adalah pengetahuan yang dimiliki seseorang dan tersimpan di dalam memori jangka panjang, berarti pengetahuan tersebut dapat diaktifkan/dipanggil kembali sebagai hasil dari suatu pencarian memori yang dilakukan secara sadar dan disengaja/tanpa disengaja secara otomatis muncul ketika seseorang dihadapkan pada permasalahan tertentu. Pengetahuan metakognitif dapat digunakan tanpa disadari. Oleh karena itu, pengetahuan yang muncul melalui kesadaran dan dilakukan secara berulang akan berubah menjadi suatu pengalaman, sehingga disebut pengalaman metakognitif.

Sebagai salah satu komponen dari pengetahuan dan tujuan pembelajaran yang harus dievaluasi sebagai hasil belajar, maka pengetahuan dan keterampilan metakognitif harus diajarkan kepada siswa (Anderson \& Krathwohl, 2001). Hal ini sejalan dengan pendapat Collins (1994) bahwa keterampilan metakognitif dapat diperoleh sedikit demi sedikit melalui pengajaran. Mengintegrasikan keterampilan metakognitif dalam pembelajaran di kelas dapat membuat tujuan tersebut dapat dicapai. Menurut Flavel (1979) dalam bukunya "Metacognition and Cognitive Monitoring", kemampuan seseorang untuk memantau berbagai macam aktivitas kognisinya dilakukan 
melalui aksi dan interaksi antara empat komponen, yaitu: a) Pengetahuan metakognisi (metacognitive knowledge), b) Pengalaman metakognisi (metacognitive experiences), c) Tujuan atau tugas-tugas (goals or tasks), dan d) Aksi atau strategi (actions or strategies). Kemampuan seseorang untuk mengendalikan kognisinya tergantung pada tindakan dan interaksi antar komponen tersebut.

$$
\text { Sedangkan Schoenfeld }
$$

mengemukakan secara lebih spesifik tiga cara untuk menjelaskan tentang metakognisi dalam pembelajaran matematika, yaitu: (a) keyakinan dan intuisi, (b) pengetahuan, dan (c) kesadarandiri (regulasi-diri). Keyakinan dan intuisi menyangkut ide-ide matematika apa saja yang disiapkan untuk memecahkan masalah matematika dan bagaimana ide-ide tersebut membentuk jalan/cara untuk memecahkan masalah matematika. Pengetahuan tentang proses berpikir menyangkut seberapa akuratnya seseorang dalam menggambar proses berpikirnya. Sedangkan kesadaran-diri atau regulasi diri menyangkut seberapa baiknya seseorang dalam menjaga dan mengatur apa yang harus dilakukan ketika memecahkan masalah dan seberapa baiknya seseorang menggunakan input dari pengamatan untuk mengarahkan aktivitas-aktivitas pemecahan masalah. Pintrich (2002) mengemukakan tiga aspek tentang hal-hal yang membangun metakognisi yaitu: (a) pengetahuan strategik (strategic knowled) (b) pengetahuan tentang tugas-tugas kognitif, termasuk pengetahuan kontekstual dan kondisional (knowledge about cognitive task,including appropriate contextual and conditioning knowledge); dan (c) pengetahuan-diri (self-knowledge).

$$
\text { Sedangkan Gagne }
$$

mengemukakan bahwa strategi kognitif adalah kapabilitas-kapabilitas yang secara internal terorganisasi yang memungkinkan siswa menggunakannya untuk mengatur cara dia belajar, mengingat, dan berpikir. Siswa menggunakan strategi kognitif ketika dia mengikuti berbagai uraian dari apa yang sedang ia baca, apa yang ia pelajari, baik yang menyangkut keterampilan intelektual maupun yang manyangkut informasi. Peranan pengetahuan strategi kognitif dalam pembelajaran sangatlah besar manfaatnya jika guru memberikan kesempatan kepada setiap siswa untuk mempelajari berbagai strategi kognitif. Semakin banyak strategi kognitif yang dipelajari siswa dalam mengikuti, mengkode, menyimpan, mentransfer, dan memecahkan masalah, maka semakin menjadikan siswa menjadi "self-learner" dan pemikir yang independen.

Anderson \& Krathwohl (2001) mengemukakan tiga macam strategi kognitif yang sangat penting untuk diajarkan kepada siswa adalah (a) strategi mengulang (rehearsal), (b) strategi elaborasi (elaboration), dan (c) strategi organisasi (organizational). Variabel lain yang terkait dengan metakognisi adalah variabel individu. Sebagai modal dasar untuk menjadi seorang siswa mandiri (self-learner) yang baik, siswa harus memiliki pengetahuan tentang kelemahan dan kelebihan dirinya dalam menghadapi tugas-tugas kognitif, yang menurut Anderson \& Krathwohl (2001) disebut pengetahuan-diri (self-knowledge). Bahkan lebih jauh siswa harus mampu memilih, menggunakan, dan memonitor strategi-strategi kognitif yang cocok dengan tipe belajar, gaya berpikir, dan gaya kognitif yang dimiliki dalam mengahadapi tugas-tugas kognitif. Misalnya, seseorang dengan tipe belajar visual harus sering menggunakan strategi elaborasi peta konsep dalam memahami materi yang sedang dipelajari. Kemampuan seperti ini merupakan salah satu komponen metakognisi yang disebut pemonitoran kognitif.

Ketika seseorang memahami informasi baru, dia sering berkata, "Saya dengar apa yang Anda katakan". Selanjutnya, pengetahuan seseorang tentang fungsi kognitifnya sendiri, serta kemampuan seseorang dalam mengatur, mengontrol dan memberdayakan fungsi kognitifnya dalam memilih strategi dalam belajar, berpikir, dan pemecahan masalah termasuk dalam strategi metakognisi. Hal ini sejalan dengan tiga langkah dasar strategi metakognisi menurut Dirkes (1985) dalam Blakey \& Spence (1990), yakni: (a) menghubungkan informasi baru pada pengetahuan yang sudah terbentuk, (b) memilih strategi-strategi berpikir dengan hati-hati, dan (c) merencanakan, memonitor, dan mengevaluasi proses-proses berpikir.

Menurut Nasution (2008:205) modul merupakan suatu unit lengkap yang berdiri sendiri dan tertulis atas suatu rangkaian kegiatan belajar yang disusun untuk membantu warga belajar mencapai sejumlah tujuan yang dirumuskan secara khusus dan jelas. Modul merupakan suatu unit program belajar mengajar 
terkecil yang secara rinci menggariskan: (1) petunjuk penggunaan yang memberi penjelasan tentang cara warga belajar menggunakan modul, (2) tujuan penggunaan modul, berisi tujuan yang akan dicapai setelah mempelajari modul, (3) materi pelajaran yang akan dicapai warga belajar, (4) lembar kegiatan warga belajar, berisikan kegiatan yang akan dilakukan baik teori maupun mengadakan percobaan, dan (5) latihan, berisikan tes yang digunakan untuk menilai ketercapaian tujuan yang telah dirumuskan. Modul adalah suatu alat pembelajaran yang didasrkan pada metode belajar sendiri yang dilakukan dengan seperangkat pembelajaran yang berisikan: petunjuk melakukan, pengetahuan yang bersifat teroi dan praktek dan evaluasi.

Finch dan Crunkilton dalam Sibuea (2000) mengatakan modul pembelajaran dapat didefinisikan sebagai suatu paket serba lengkap yang mencakup serangkaian rencana pengalaman-pengalaman belajar yang dirancang untuk membantu siswa mencapai tujuan khusus. Oleh sebab itu modul harus yaitu: (1) ada bagian modul yang diisi sendiri oleh siswa dan tidak perlu bertanya kepada guru apa yang harus dikerjakan berikutnya, (2) dapat digunakan belajar sendiri sesuai dengan karakteristik siswa agar dapat maju sesuai kecepatan siswa, menerima penilaian kemajuan melalui masingmasing modul, fokus untuk mencapai tujuan khusus yang dapat diukur dalam tiap-tiap modul, (3) paket lengkap, (4) berisikan tujuan dan pengalaman belajar, (5) berisikan mekanisme untuk menilai apakah siswa sudah mencapai tujuan. Dalam mengembangkan modul ada 6 hal yang harus dipenuhi yaitu: (1) ada pendahuluan, (2)dinyatakan tujuan pelajaran, (3) dilakukan penilaian awal dan akhir (4) terdapat pengalaman belajar, (5) dituliskan sumber materi belajaran, dan (6) di uji coba.

Disebut modul adalah lengkap oleh karena melalui pemanfaatan modul siswa tidak perlu bertanya kepada guru mengenai bahanbahan yang harus di gunakan karena dalam modul telah di uraikan informasi dan petunjukpetunjuk. Dalam setiap modul diuraikan pula pengerahan mengenai apa yang harus di lakukan, bagaimana program melakukan praktek dan bahan atau materi apa yang digunakan, juga memberi arti bahwa modul menggambarkan urutan yang sistematis dan logis mengenai modul dalam memulai dan mengakhiri pelajaran secara tepat. Menurut Hall dan Jones dalam
Sibuea (2000) meluasnya penggunaan pengajaran dengan modul ini karena beberapa alasan, yaitu (1) melalui penggunaan modul dapat di layani siswa-siswa dengan latar belakang yang beraneka ragam, (2) melalui penggunaan modul maka pemanfaatan sumber daya manusia lebih efektif, (3) berdasarkan beberapa riset di temukan bahwa kualitas pengajaran akan meningkat bila menggunakan modul, dan (4) melalui penggunaan modul dapat diberikan pengajaran dalam bentuk keterampilan, demonstrasi dan sebagainya.

Rumusan masalah penelitian dan pengembangan ini adalah Apakah pengembangan modul fisika berbasis metakognisi layak digunakan sebagai media pembelajaran kelas XI IPA SMA pada materi pokok getaran harmonik sederhana?

\section{METODE}

Penelitian ini dilaksanakan di SMA Negeri 1 Sunggal Jalan Sei Mencirim - Sei Semayang Kec. Sunggal, pada siswa kelas XI IPA pada pelajaran Fisika materi pokok getaran harmonik sederhana. Penelitian pengembangan ini merujuk pada langkah-langkah penelitian pengembangan model Borg and Gall , pengembangan modul merujuk pada Dick and Carey. Langkah-langkah yang dilakukan dalam pengembangan (Borg and Gall) adalah: (1) tahap analisis kebutuhan, (2) tahap perancangan modul, dan (3) tahap uji coba (validasi). Pada tahap analisis, kegiatan yang dilakukan berupa analisis beberapa aspek pembelajaran yang akan dicapai sesuai dengan materi pembelajaran. Analisis aspek tersebut dibagi menjadi 3 tahap, yaitu : melakukan studi pendahuluan, mengidentifikasi kebutuhan, analisis pembelajaran.

Modul pembelajaran yang akan dikembangkan adalah untuk siswa kelas XI IPA semester ganjil K-13 dengan standar kompetensi yaitu getaran harmonik sederhana. Siswa diharapkan mampu menganalisis karakteristik gerak pada getaran pegas, menganalisis hubungan antara periode getaran dengan massa beban dan menganalisis gaya, simpangan, kecepatan, percepatan, energi kinetik, energi potensial dan energi mekanik pada gerak harmonik sederhana.

Adapun tahapan dari desain uji coba pengembangan modul dalam penelitian ini adalah sebagai berikut :

a) Validasi ahli desain pembelajaran 
b) Validasi ahli materi pembelajaran/media pembelajaran

c) Analisis konseptual

d) Revisi pengembangan (tahap I), berdasarkan penilaian yang berupa masukan, kritik atau saran dari 2 orang ahli materi, 1 orang ahli desain pembelajaran dan 2 orang ahli media pembelajaran yang berpendidikan minimal S2 untuk dilakukan perbaikan

e) Uji coba terhadap siswa (perorangan dan kelompok kecil)

f) Penilaian terhadap program ini berdasarkan angket yang telah diisi oleh 3 siswa dan 9 siswa

g) Analisis konseptual dan produk

h) Revisi produk (tahap II)

i) Uji coba lapangan terhadap siswa

j) Penilaian mengenai kelayakan produk

k) Analisis empiric (tahap III)

1) Revisi kecil.

Uji coba produk dalam

pengembangan ini dilaksanakan dengan melalui beberapa langkah sebagai berikut:

a) Langkah pertama menentukan sasaran uji coba yaitu ahli materi, ahli desain pembelajaran dan ahli media pembelajaran. Masukan yang diharapkan dari para ahli masing-masing adalah rancangan modul, aspek pembelajaran dan kebenaran maupun kecermatan dari isi produk serta desain grafis modul yang dikembangkan. Dari siswa dilakukan untuk memperoleh masukan dari aspek kemanfaatan, kemudahan, dan kemenarikan produk.

b) Langkah kedua menetapkan subjek uji coba dengan penunjukkan ini selain didasarkan pada kriteria pendidikan, keahlian, juga ketersediaan waktu dan tenaga untuk memberikan data yang diperlukan bagi produk sebelum diuji cobakan kepada pemakai di lapangan.

c) Langkah ketiga pelaksanaan tinjauan ahli sebelum uji coba perorangan dan lapangan, terlebih dahulu produk diberikan kepada para ahli untuk mendapatkan saran dan masukan sesuai dengan keahliannya masing-masing yang kemudian dianalisis dan disimpulkan sebagai dasar dalam melakukan perbaikan terhadap produk (revisi I).

d) Langkah keempat uji coba II (perorangan dan kelompok kecil). Pada langkah ini produk telah diperbaiki pada revisi I (langkah 3) dan angket penilaian diberikan pada pemakai secara perorangan dan kelompok kecil yang tujuannya untuk mengetahui kesahihan produk setelah diperbaiki berdasarkan tinjauan para ahli tersebut. Masukan-masukan dari uji coba II ini selanjutnya dipakai sebagai dasar dalam melakukan perbaikan-perbaikan terhadap produk (revisi II).

e) Langkah kelima uji coba III (lapangan). Uji coba ini dilakukan untuk mengetahui apakah masih terdapat kekurangankekurangan yang perlu diperbaiki dari produk yang dikembangkan setelah diskusi baik berdasarkan tinjauan ahli maupun pada uji coba perorangan dan kelompok kecil. Jika masih terdapat kekurangannya maka berdasarkan masukan diperoleh akan dilakukan perbaikan III (revisi III). Jika tidak, maka dapat dinyatakan layak sebagai sumber sahih di lapangan.

Data yang akan dikumpulkan yaitu data tentang kebutuhan modul beserta kelengkapannya dalam bentuk kualitatif. Data kualitatif dikumpulkan dengan menggunakan lembaran survey, interview, dan angket atau kuesioner.

Uji coba dalam penelitian ini dilakukan dengan membagikan angket. Angket diberikan kepada siswa untuk mengetahui keputusan siswa terhadap modul pembelajaran yang dikembangkan. Angket dibuat dalam skala 1 sampai 4 dengan kriteria sebagai berikut :

1) $4=$ jika sangat baik/sangat cocok/sangat lengkap/sangat memadai

2) $3=$ jika baik/cocok/lengkap/memadai

3) $2=$ jika kurang baik/kurang cocok/kurang lengkap/kurang memadai

4) $1=$ jika tidak baik/tidak cocok/tidak lengkap/tidak memadai

Analisis data dalam penelitian ini menggunakan analisis deskriptif kuantitatif. Data kualitatif yang berupa pernyataan sangat baik/sangat cocok/sangat lengkap/sangat memadai, baik/cocok/lengkap/memadai, kurang baik/kurang cocok/kurang lengkap/kurang memadai dan tidak baik/tidak cocok/tidak lengkap/tidak memadai, diubah menjadi data kuantitatif dengan skala nilai 1 sampai 4 . Adapun kriteria penilaian validasi modul oleh para ahli dapat dilihat pada table 1 di bawah ini. 
Tabel 1. Rentang Skor Kriteria Penilaian Validasi Ahli

\begin{tabular}{|c|c|c|c|l|}
\hline No & $\begin{array}{c}\text { Ahli Materi } \\
\text { Pembelajaran }\end{array}$ & $\begin{array}{c}\text { Ahli Desain } \\
\text { Pembelajaran }\end{array}$ & $\begin{array}{c}\text { Ahli Media } \\
\text { Pembelajaran }\end{array}$ & \multicolumn{1}{|c|}{ Kriteria Penilaian } \\
\hline 1 & 76 s/d 57 & 84 s/d 63 & 72 s/d 54 & $\begin{array}{l}\text { layak untuk digunakan setelah } \\
\text { diperbaiki }\end{array}$ \\
\hline 2 & 56 s/d 39 & 62 s/d 42 & 53 s/d 36 & $\begin{array}{l}\text { belum layak untuk digunakan dan } \\
\text { perlu perbaikan }\end{array}$ \\
\hline 3 & 38 s/d 19 & 41 s/d 21 & 35 s/d 18 & $\begin{array}{l}\text { belum layak untuk digunakan dan } \\
\text { perlu banyak perbaikan }\end{array}$ \\
\hline
\end{tabular}

Kriteria penilaian validasi ahli modul pembelajaran menggunakan Skala Likert yang dianalisis secara deskriptif persentase dengan rumus sebagai berikut.

Dimana :

$$
X=\frac{R}{N} x 100 \%
$$

$\mathrm{X}$ : Nilai yang diharapkan (dicari)

$\mathrm{R}$ : Jumlah skor dari item atau soal yang dijawab benar

$\mathrm{N}$ : Skor maksimum dari tes tersebut

Dengan kriteria rentangan skor persentase penilaian menurut Arikunto (1998:246) seperti yang tertulis pada Tabel 2. berikut ini.

Tabel 2. Kriteria Penilaian Modul Pembelajaran

\begin{tabular}{|c|l|c|}
\hline No & \multicolumn{1}{|c|}{ Kriteria } & Rentang Skor \\
\hline 1 & Sangat Baik & $75 \% \leq X \leq 100 \%$ \\
\hline 2 & Baik & $55 \% \leq X<75 \%$ \\
\hline 3 & Kurang Baik & $40 \% \leq X<55 \%$ \\
\hline 4 & Tidak Baik & $X<40 \%$ \\
\hline
\end{tabular}

\section{HASIL DAN PEMBAHASAN}

Hasil

Hasil validasi berupa skor penilaian terhadap komponen-komponen modul pembelajaran fisika berbasis metakognisi pada kualitas materi pembelajaran dapat dilihat pada tabel 3 .

Tabel 3. Skor Penilaian Ahli Materi Pembelajaran

\begin{tabular}{|c|l|c|c|c|c|}
\hline \multirow{2}{*}{ No } & \multicolumn{1}{|c|}{ Aspek } & \multicolumn{2}{|c|}{ Reviewer } & Rata & Persentas \\
\cline { 3 - 5 } & & $\mathbf{1}$ & $\mathbf{2}$ & -rata & $\begin{array}{c}\text { e Skor } \\
\text { Ideal }\end{array}$ \\
\hline 1 & Komponen Kelayakan Isi & 38 & 39 & 38,5 & $87,5 \%$ \\
\hline 2 & $\begin{array}{l}\text { Komponen Kelayakan } \\
\text { Penyajian }\end{array}$ & 29 & 27 & 28 & $87,5 \%$ \\
\hline \multicolumn{3}{|c|}{ Rata - rata Skor Total } & & 66,5 & $87,5 \%$ \\
\hline
\end{tabular}

Hasil validasi berupa skor penilaian komponen modul pembelajaran fisika berbasis metakognisi. Menurut ahli desain pembelajaran kualitas modul yang dikembangkan sudah baik dan layak untuk diujicobakan.

Tabel 4. Skor Penilaian Ahli Desain Pembelajaran

\begin{tabular}{|c|l|c|c|c|}
\hline No & \multicolumn{1}{|c|}{ Aspek } & Reviewer & Rata-rata & Persentase Skor Ideal \\
\hline 1 & Pendahuluan & 16 & 16 & $100 \%$ \\
\hline 2 & Tujuan & 20 & 20 & $100 \%$ \\
\hline 3 & Tes Akhir & 14 & 14 & $87,5 \%$ \\
\hline 4 & Pengalaman Belajar & 20 & 20 & $100 \%$ \\
\hline 5 & Sumber Belajar & 12 & 12 & $100 \%$ \\
\hline
\end{tabular}




$$
\begin{array}{l|c|r}
\text { Rata - rata Skor Total } & 82 & 97,6 \%
\end{array}
$$

Validasi ahli media pembelajaran dilakukan oleh dua orang ahli media pembelajaran. Ahli media pembelajaran memvalidasi produk aspek-aspek media pembelajaran diantaranya pada aspek desain kulit modul yang terdiri dari kemenarikan, penggunaan huruf dan ilustrasi cover, aspek bagian modul yang terdiri dari pendahuluan, tujuan, tes akhir, pengalaman belajar dan sumber belajar, dan aspek desain isi modul yang terdiri dari unsur taat letak dan tipografi huruf serta ilustrasi isi. Hasil validasi berupa skor penilaian komponen modul pembelajaran fisika berbasis metakognisi.

Tabel 5. Skor Penilaian Ahli Media Pembelajaran

\begin{tabular}{|c|c|c|c|c|c|}
\hline \multirow[b]{2}{*}{ No } & \multirow[b]{2}{*}{ Aspek } & \multicolumn{2}{|c|}{ Reviewer } & \multirow[b]{2}{*}{$\begin{array}{l}\text { Rata } \\
\text {-rata }\end{array}$} & \multirow{2}{*}{$\begin{array}{c}\text { Persentas } \\
\text { e Skor } \\
\text { Ideal }\end{array}$} \\
\hline & & 1 & 2 & & \\
\hline 1 & Desain Kulit Modul & 22 & 20 & 21 & $87,5 \%$ \\
\hline 2 & Desain Isi Modul & 39 & 40 & 39,5 & $82,29 \%$ \\
\hline \multicolumn{4}{|c|}{ Rata - rata Skor Total } & 60,5 & $84,03 \%$ \\
\hline
\end{tabular}

Penilaian dan masukkan uji coba ini adalah tentang penyajian produk pembelajaran meliputi kelayakan isi, kelayakan penyajian dan kelayakan bahasa. Data hasil uji coba perorangan dapat dilihat pada tabel 6 .

Tabel 6. Data Hasil Angket Uji Coba Perorangan

\begin{tabular}{|c|c|c|c|c|c|c|c|}
\hline \multirow{2}{*}{ Aspek } & \multirow{2}{*}{ Diskripsi } & \multicolumn{3}{|c|}{ Reviewer } & \multirow{2}{*}{$\begin{array}{l}\text { Jlh } \\
\text { Skor }\end{array}$} & \multirow{2}{*}{$\begin{array}{c}\text { Rata- } \\
\text { rata }\end{array}$} & \multirow{2}{*}{$\begin{array}{l}\text { Persentase } \\
\text { Skor Ideal } \\
\end{array}$} \\
\hline & & 1 & 2 & 3 & & & \\
\hline \multirow{4}{*}{$\begin{array}{l}\text { Kelayakan } \\
\text { Isi }\end{array}$} & $\begin{array}{l}\text { Cakupan materi yang ada dalam modul jelas dan } \\
\text { runtut sehingga mudah saya pahami }\end{array}$ & 3 & 3 & 3 & 9 & 3 & $75 \%$ \\
\hline & $\begin{array}{l}\text { Masalah yang disajikan dalam materi modul, } \\
\text { sesuai dengan kehidupan sehari-hari saya }\end{array}$ & 4 & 2 & 4 & 10 & 3,33 & $83,33 \%$ \\
\hline & $\begin{array}{l}\text { Saya merasa senang jika pembelajaran } \\
\text { menggunakan modul ini }\end{array}$ & 4 & 3 & 3 & 10 & 3,33 & $83,33 \%$ \\
\hline & $\begin{array}{l}\text { Penggunaan modul dalam kegiatan pembelajaran } \\
\text { akan lebih mudah untuk saya pahami }\end{array}$ & 4 & 2 & 3 & 9 & 3 & $75 \%$ \\
\hline \multicolumn{5}{|c|}{ Jumlah Skor } & 38 & 12,66 & $\begin{array}{l}\text { Rerata }= \\
79,16 \%\end{array}$ \\
\hline \multirow{5}{*}{$\begin{array}{l}\text { Kelayakan } \\
\text { Penyajian }\end{array}$} & $\begin{array}{l}\text { Penyajian modul membuat saya tertarik untuk } \\
\text { membacanya }\end{array}$ & 3 & 4 & 4 & 11 & 3,66 & $91,67 \%$ \\
\hline & $\begin{array}{l}\text { Modul dilengkapi dengan gambar dan tabel yang } \\
\text { jelas }\end{array}$ & 3 & 4 & 4 & 11 & 3,66 & $91,67 \%$ \\
\hline & $\begin{array}{l}\text { Modul dilengkapi dengan rangkuman materi } \\
\text { yang mencakup seluruh isi materi }\end{array}$ & 3 & 3 & 4 & 10 & 3,33 & $83,33 \%$ \\
\hline & Modul dilengkapi dengan glosarium & 4 & 4 & 3 & 11 & 3,66 & $91,67 \%$ \\
\hline & $\begin{array}{l}\text { Modul dilengkapi dengan daftar pustaka yang } \\
\text { jelas }\end{array}$ & 4 & 3 & 4 & 11 & 3,66 & $91,67 \%$ \\
\hline \multicolumn{5}{|c|}{ Jumlah Skor } & 54 & 13,32 & $\begin{array}{l}\text { Rerata }= \\
90 \%\end{array}$ \\
\hline \multirow{3}{*}{$\begin{array}{l}\text { Kelayakan } \\
\text { Bahasa }\end{array}$} & Bahasa yang digunakan dalam modul sesuai EYD & 3 & 3 & 4 & 10 & 3,33 & $83,33 \%$ \\
\hline & $\begin{array}{lccc}\text { Bahasa } & \text { yang } & \text { digunakan dalam } & \text { modul } \\
\text { komunikatif dan mudah saya pahami } & \\
\end{array}$ & 4 & 3 & 3 & 10 & 3,33 & $83,33 \%$ \\
\hline & $\begin{array}{l}\text { Struktur kalimat yang digunakan dalam modul } \\
\text { jelas dan sederhana }\end{array}$ & 3 & 4 & 4 & 11 & 3,66 & $91,67 \%$ \\
\hline \multicolumn{5}{|c|}{ Jumlah Skor } & 31 & 10,32 & $\begin{array}{l}\text { Rerata = } \\
86,11 \%\end{array}$ \\
\hline \multicolumn{7}{|c|}{ Persentase Skor Total } & $85,09 \%$ \\
\hline
\end{tabular}


Uji coba kelompok kecil ini digunakan sebagai pengalaman awal sebelum produk diujicobakan ke lapangan. Data hasil uji coba kelompok kecil dapat dilihat pada table 7. berikut:

Tabel 7. Data Hasil Angket Uji Coba Kelompok Kecil

\begin{tabular}{|c|c|c|c|c|c|c|c|c|}
\hline \multirow[b]{2}{*}{ Aspek } & \multirow[b]{2}{*}{ Diskripsi } & \multicolumn{4}{|c|}{ Skor } & \multirow{2}{*}{$\begin{array}{c}\text { Jlh } \\
\text { Sko } \\
\text { r } \\
\end{array}$} & \multirow{2}{*}{$\begin{array}{l}\text { Rata } \\
\text {-rata }\end{array}$} & \multirow{2}{*}{$\begin{array}{c}\text { Persentas } \\
\text { e Skor } \\
\text { Ideal } \\
\end{array}$} \\
\hline & & 4 & 3 & 2 & 1 & & & \\
\hline \multirow{4}{*}{$\begin{array}{l}\text { Kelayaka } \\
\text { n Isi }\end{array}$} & $\begin{array}{l}\text { Cakupan materi yang ada dalam modul } \\
\text { jelas dan runtut sehingga mudah saya } \\
\text { pahami }\end{array}$ & 9 & - & - & - & 36 & 4 & $100 \%$ \\
\hline & $\begin{array}{l}\text { Masalah yang disajikan dalam materi } \\
\text { modul, sesuai dengan kehidupan } \\
\text { sehari-hari saya }\end{array}$ & 9 & - & - & - & 36 & 4 & $100 \%$ \\
\hline & $\begin{array}{l}\text { Saya merasa senang jika pembelajaran } \\
\text { menggunakan modul ini }\end{array}$ & 1 & 8 & - & - & 25 & 2,6 & $69,44 \%$ \\
\hline & $\begin{array}{l}\text { Penggunaan modul dalam kegiatan } \\
\text { pembelajaran akan lebih mudah untuk } \\
\text { saya pahami }\end{array}$ & 2 & 7 & - & - & 27 & 3 & $75 \%$ \\
\hline \multicolumn{6}{|c|}{ Jumlah Skor } & 124 & 13,6 & $\begin{array}{l}\text { Rerata = } \\
86,11 \%\end{array}$ \\
\hline \multirow{5}{*}{$\begin{array}{l}\text { Kelayaka } \\
\mathrm{n} \\
\text { Penyajia } \\
\mathrm{n}\end{array}$} & $\begin{array}{l}\text { Penyajian modul membuat saya tertarik } \\
\text { untuk membacanya }\end{array}$ & 7 & 2 & - & - & 34 & 3,7 & $94,44 \%$ \\
\hline & $\begin{array}{l}\text { Modul dilengkapi dengan gambar dan } \\
\text { tabel yang jelas }\end{array}$ & 7 & 2 & - & - & 34 & 3,7 & $94,44 \%$ \\
\hline & $\begin{array}{l}\text { Modul dilengkapi dengan rangkuman } \\
\text { materi yang mencakup seluruh isi } \\
\text { materi }\end{array}$ & 9 & - & - & - & 36 & 4 & $100 \%$ \\
\hline & Modul dilengkapi dengan glosarium & 9 & - & - & - & 36 & 4 & $100 \%$ \\
\hline & $\begin{array}{l}\text { Modul dilengkapi dengan daftar pustaka } \\
\text { yang jelas }\end{array}$ & 9 & - & - & - & 36 & 4 & $100 \%$ \\
\hline \multicolumn{6}{|c|}{ Jumlah Skor } & 176 & 19,55 & $\begin{array}{l}\text { Rerata }= \\
97,78 \%\end{array}$ \\
\hline \multirow{3}{*}{$\begin{array}{l}\text { Kelayaka } \\
\text { n Bahasa }\end{array}$} & $\begin{array}{l}\text { Bahasa yang digunakan dalam modul } \\
\text { sesuai EYD }\end{array}$ & 9 & - & - & - & 36 & 4 & $100 \%$ \\
\hline & $\begin{array}{l}\text { Bahasa yang digunakan dalam modul } \\
\text { komunikatif dan mudah saya pahami }\end{array}$ & 5 & 4 & - & - & 32 & 3,5 & $88,89 \%$ \\
\hline & $\begin{array}{l}\text { Struktur kalimat yang digunakan dalam } \\
\text { modul jelas dan sederhana }\end{array}$ & 5 & 4 & - & - & 32 & 3,5 & $88,89 \%$ \\
\hline \multicolumn{6}{|c|}{ Jumlah Skor } & 100 & 11 & $\begin{array}{l}\text { Rerata = } \\
92,59 \%\end{array}$ \\
\hline \multicolumn{6}{|c|}{ Persentase Skor Total } & & & $92,16 \%$ \\
\hline
\end{tabular}

Uji coba lapangan menghasilkan data-data yang nantinya akan mengukur kelayakan dari produk yang dikembangkan, serta untuk mengetahui manfaat produk tersebut bagi pemakainya. Hasil evaluasi uji coba lapangan dapat dilihat pada tabel 8.

Tabel 8. Data Hasil Angket Uji Coba Lapangan

\begin{tabular}{|c|c|c|c|c|c|c|c|c|}
\hline \multirow[b]{2}{*}{ Aspek } & \multirow[b]{2}{*}{ Diskripsi } & \multicolumn{4}{|c|}{ Skor } & \multirow{2}{*}{$\begin{array}{c}\text { Jlh } \\
\text { Sko } \\
\text { r } \\
\end{array}$} & \multirow{2}{*}{$\begin{array}{l}\text { Rata } \\
\text {-rata }\end{array}$} & \multirow{2}{*}{$\begin{array}{c}\text { Persentas } \\
\text { e Skor } \\
\text { Ideal } \\
\end{array}$} \\
\hline & & 4 & 3 & 2 & 1 & & & \\
\hline $\begin{array}{l}\text { Kelaya } \\
\text { kan Isi }\end{array}$ & $\begin{array}{l}\text { Cakupan materi yang ada dalam } \\
\text { modul jelas dan runtut sehingga } \\
\text { mudah saya pahami }\end{array}$ & 16 & 18 & - & - & 118 & 3,47 & $86,76 \%$ \\
\hline
\end{tabular}




\begin{tabular}{|c|c|c|c|c|c|c|c|c|}
\hline \multirow[b]{2}{*}{ Aspek } & \multirow[b]{2}{*}{ Diskripsi } & \multicolumn{4}{|c|}{ Skor } & \multirow{2}{*}{$\begin{array}{c}\text { Jlh } \\
\text { Sko } \\
\text { r }\end{array}$} & \multirow{2}{*}{$\begin{array}{l}\text { Rata } \\
\text {-rata }\end{array}$} & \multirow{2}{*}{$\begin{array}{c}\text { Persentas } \\
\text { e Skor } \\
\text { Ideal } \\
\end{array}$} \\
\hline & & 4 & 3 & 2 & 1 & & & \\
\hline & $\begin{array}{l}\text { Masalah yang disajikan dalam materi } \\
\text { modul, sesuai dengan kehidupan } \\
\text { sehari-hari saya }\end{array}$ & 18 & 15 & 1 & - & 117 & 3,44 & $86,02 \%$ \\
\hline & $\begin{array}{l}\text { Saya merasa senang jika pembelajaran } \\
\text { menggunakan modul ini }\end{array}$ & 11 & 23 & - & - & 113 & 3,33 & $83,08 \%$ \\
\hline & $\begin{array}{l}\text { Penggunaan modul dalam kegiatan } \\
\text { pembelajaran akan lebih mudah untuk } \\
\text { saya pahami }\end{array}$ & 17 & 17 & - & - & 119 & 3,5 & $87,5 \%$ \\
\hline \multicolumn{6}{|c|}{ Jumlah Skor } & 467 & 13,74 & $\begin{array}{c}\text { Rerata }= \\
85,84 \%\end{array}$ \\
\hline \multirow{5}{*}{$\begin{array}{l}\text { Kelaya } \\
\text { kan } \\
\text { Penyaji } \\
\text { an }\end{array}$} & $\begin{array}{l}\text { Penyajian modul membuat saya } \\
\text { tertarik untuk membacanya }\end{array}$ & 16 & 18 & - & - & 118 & 3,47 & $86,76 \%$ \\
\hline & $\begin{array}{l}\text { Modul dilengkapi dengan gambar dan } \\
\text { tabel yang jelas }\end{array}$ & 26 & 8 & - & - & 128 & 3,76 & $94,12 \%$ \\
\hline & $\begin{array}{l}\text { Modul dilengkapi dengan rangkuman } \\
\text { materi yang mencakup seluruh isi } \\
\text { materi }\end{array}$ & 19 & 14 & 1 & - & 120 & 3,53 & $88,23 \%$ \\
\hline & Modul dilengkapi dengan glosarium & 26 & 8 & - & - & 128 & 3,76 & $94,12 \%$ \\
\hline & $\begin{array}{l}\text { Modul dilengkapi dengan daftar } \\
\text { pustaka yang jelas }\end{array}$ & 30 & 4 & - & - & 132 & 3,88 & $97,06 \%$ \\
\hline \multicolumn{6}{|c|}{ Jumlah Skor } & 626 & 18,4 & $\begin{array}{l}\text { Rerata }= \\
92,06 \%\end{array}$ \\
\hline \multirow{3}{*}{$\begin{array}{l}\text { Kelaya } \\
\text { kan } \\
\text { Bahasa }\end{array}$} & $\begin{array}{l}\text { Bahasa yang digunakan dalam modul } \\
\text { sesuai EYD }\end{array}$ & 14 & 9 & 1 & - & 115 & 3,38 & $84,56 \%$ \\
\hline & $\begin{array}{l}\text { Bahasa yang digunakan dalam modul } \\
\text { komunikatif dan mudah saya pahami }\end{array}$ & 15 & 19 & - & - & 117 & 3,44 & $86,02 \%$ \\
\hline & $\begin{array}{l}\text { Struktur kalimat yang digunakan } \\
\text { dalam modul jelas dan sederhana }\end{array}$ & 16 & 18 & - & - & 118 & 3,47 & $86,76 \%$ \\
\hline \multicolumn{6}{|c|}{ Jumlah Skor } & 350 & 10,29 & $\begin{array}{c}\text { Rerata }= \\
\mathbf{8 5 , 7 8 \%}\end{array}$ \\
\hline \multicolumn{8}{|c|}{ Persentase Skor Total } & $\mathbf{8 7 , 8 9 \%}$ \\
\hline
\end{tabular}

Tabel 9. Persentase Rata-rata Hasil Penilaian Pada Uji Coba Lapangan

\begin{tabular}{|c|l|c|c|}
\hline No. & \multicolumn{1}{|c|}{ Kategorisasi } & $\begin{array}{c}\text { Persentase rata- } \\
\text { rata }\end{array}$ & Kriteria \\
\hline 1 & Aspek Kelayakan Isi & $85,84 \%$ & Sangat Baik \\
\hline 2 & Aspek Kelayakan Penyajian & $92,06 \%$ & Sangat Baik \\
\hline 3 & Aspek Kelayakan Bahasa & $85,78 \%$ & Sangat Baik \\
\hline \multicolumn{2}{r|}{ Rata-rata } & $87,89 \%$ & Sangat Baik \\
\hline
\end{tabular}

Hasil rangkuman persentase skor total dari hasil validasi ahli dan uji coba modul pembelajaran dapat dilihat pada tabel 10 dibawah ini.

Tabel 10. Persentase Skor Total Hasil Penilaian Validasi Ahli dan Uji Coba Modul Pembelajaran

\begin{tabular}{|c|l|c|c|}
\hline No. & \multicolumn{1}{|c|}{ Responden } & Persentase Rata-rata & Kriteria \\
\hline 1 & Ahli materi pembelajaran & $87,5 \%$ & Sangat Baik \\
\hline 2 & Ahli desain pembelajaran & $97,61 \%$ & Sangat Baik \\
\hline 3 & Ahli media pembelajaran & $84,03 \%$ & Sangat Baik \\
\hline 4 & Uji coba perorangan & $85,09 \%$ & Sangat Baik \\
\hline
\end{tabular}




\begin{tabular}{|l|l|c|c|}
\hline 5 & Uji coba kelompok kecil & $92,16 \%$ & Sangat Baik \\
\hline 6 & Uji coba lapangan & $87,89 \%$ & Sangat Baik \\
\hline \multicolumn{2}{|c|}{ Rata-rata } & $89,05 \%$ & Sangat Baik \\
\hline
\end{tabular}

\section{Pembahasan}

Produk pengembangan modul pembelajaran fisika berbasis metakognisi merupakan materi pembelajaran yang telah dikembangkan dengan memperhatikan aspek pembelajaran. Penelitian pengembangan produk yang dilakukan ini diarahkan untuk menghasilkan suatu produk berupa modul pembelajaran fisika berbasis untuk siswa yang digunakan untuk meningkatkan proses pembelajaran maupun kompetensi siswa. Oleh sebab itu proses penelitian dilakukan dan diawali dengan, (1) studi pendahuluan, (2) kemudian mendesain media pembelajaran, (3) melakukan validasi produk dan melakukan revisi dan penyempurnaan berdasarkan analisis data validasi dari ahli materi, (4) ahli desain pembelajaran yang dilanjutkan dengan ui coba perorangan, uji coba kelompok kecil, dan uji coba lapangan sehingga dihasilkan modul pembelajaran yang layak digunakan sesuai dengan karakteristik bidang studi dan siswa sebagai pengguna.

Aspek yang direvisi dan disempurnakan berdasarkan analisis data dan uji coba serta masukan dari ahli materi, ahli desain pembelajaran dan ahli media pembelajaran serta siswa selaku pengguna modul pembelajaran, bertujuan untuk menggali beberapa aspek yang lazim dalam proses pengembangan suatu produk. Variabel-variabel modul pembelajaran memiliki nilai rata-rata sangat baik.

\section{PENUTUP}

Berdasarkan rumusan, tujuan, hasil dan pembahasan penelitian pengembangan modul pembelajaran fisika berbasis metakognisi yang dikemukakan sebelumnya maka dapat disimpulkan bahwa modul pembelajaran fisika berbasis metakognisi yang dihasilkan layak untuk digunakan. Kelayakan ini diperoleh dari hasil penilaian validasi ahli dan uji coba. Adapun hasil penilaian tersebut adalah sebagai berikut:

1. Hasil validasi dari ahli materi terhadap modul pembelajaran fisika berbasis metakognisi yang dikembangkan menunjukkan bahwa: (1) kualitas aspek kelayakan isi memperoleh nilai sebesar $87,5 \%$, (2) kualitas aspek kelayakan penyajian isi memperoleh nilai sebesar $87,5 \%$. Dengan demikian persentase skor total penilaian ahli materi terhadap modul pembelajaran fisika berbasis metakognisi adalah 87,5\% dan secara keseluruhan termasuk kategori "sangat baik".

2. Hasil validasi dari ahli desain pembelajaran terhadap modul pembelajaran fisika berbasis metakognisi yang dikembangkan menunjukkan bahwa kualitas desain pembelajaran memperoleh persentase skor total sebesar $97,61 \%$ dan termasuk kategori "sangat baik".

3. Hasil validasi dari ahli media pembelajaran terhadap modul pembelajaran fisika berbasis metakognisi yang dikembangkan menunjukkan bahwa : (1) kualitas desain kulit modul memperoleh persentase skor $87,5 \%$, dan (2) kualitas desain isi modul memperoleh persentase skor 82,29\%. Dengan demikian persentase skor total penilaian ahli media pembelajaran terhadap modul pembelajaran fisika berbasis metakognisi adalah $84,03 \%$ dan secara keseluruhan termasuk kategori "sangat baik"

4. Menurut tanggapan siswa pada uji coba perorangan dinyatakan bahwa modul pembelajaran termasuk kategori "sangat baik" dengan rata-rata persentase $85,09 \%$ dimana aspek kelayakan isi memperoleh persentase sebesar 79,16\%, kelayakan penyajian memperoleh persentase sebesar 90 $\%$ dan kelayakan bahasa memperoleh persentase sebesar 98,38\%.

5. Menurut tanggapan siswa pada uji coba kelompok kecil dinyatakan bahwa modul pembelajaran termasuk kategori "sangat baik" dengan rata-rata persentase $92,16 \%$ dimana aspek kelayakan isi memperoleh persentase sebesar $81,11 \%$, kelayakan penyajian memperoleh persentase sebesar 97,78\% dan kelayakan bahasa memperoleh persentase sebesar $92,59 \%$.

6. Menurut tanggapan siswa pada uji coba lapangan dinyatakan bahwa modul pembelajaran termasuk kategori "sangat baik" dengan rata-rata persentase $87,89 \%$ dimana aspek kelayakan isi memperoleh 
persentase sebesar 85,84\%, kelayakan penyajian memperoleh persentase sebesar $92,06 \%$ dan kelayakan bahasa memperoleh persentase sebesar $85,78 \%$.

\section{DAFTAR PUSTAKA}

Anderson, D. \& Nason, S. 2006. Predator of Knowledge Construction : Interpreting Students, Metacognition in an Amusement Park Physics Program. Wiley Periodicals, Inc. Science Education DOI 10.1002/sce

Anderson, L.W. \& Krathwohl, D.R. 2001. A Taxonomy For Learning, Teaching, and Assesing (A Revision of Bloom's Taxonomy of Educational Objectives). New York : Addision Wesley Longma, Inc.

Brown, A. L., \& DeLoache, J. S. 1978. Skills, plans, and self-regulation. In R. S. Siegel (Ed.), Children_s thinking: What develops? (pp. 3-35). Hillsdale, N.J.: Erlbaum.

Campbell, J. 2007. Using Metacogs to Collaborate with Students to Improve Teaching and Learning in Physics. Educational Insights Volume 11, Number 2.

Chun Yi Shen \& Hsiu Cuan Liu. 2011. Metacognitive Skills Development: A Web-Based Aprroach in Higher Education. The Turkish Online Journal of Educational Technology, Volume 10 Issue 2

Collins, N. D. 1994. Metacognition and Reading To Learn. New York: ERIC Clearinghouse on Information Resources Syracusa NY.

Desoete, A., 2001. Off-Line Metacognition in Children with Mathematics Learning Disabilities. Faculteit Psychologies en Pedagogische Wetenschappen Universiteit-Gent. Available (https:/archive.ugent.be/retrieve/917/801 001505476.pdf)

Dharma, Surya. 2008. Penulisan Modul. Jakarta : Direktorat Tenaga Kependidikan, Dirjen PMPTK.

Dick, W. \& Carey, L. 1996. The Systematics Design of Instruction. New York : Longman

Flavell, J. 1979. Metacognition and Cognitive Monitoring: A New Area of Cognitive Developmental Inquiry. American Psychologist, 34: 906 - 911
Gama, C. 2004. Integrating Metacognition Instruction in Interactive Learning Environments. Submitted for the degree of D. Phil. http://www.dcc.utba. br/ claudiag/thesis/ indexGama.pdf.

Georghiades, P. 2000. Beyond Conceptual Change Learning in Science Education: Focusing on Transfer, Durability and Metacognition. Educational Research, 42 (2), 119-139.

Gok, T. 2010. The General Assessment of Problem Solving Proscesses and Metacognition in Physics Education. Eurasian Journal of Physics and Chemistry Education 2(2): 110-122, 2010.

Heller, K., \& Heller, P. 1999. Problem-Solving Laboratories. Cooperative Group problem-solving in physics. University of Minnesota

Joyce, B. \& Marsha. W. 1996. Models of Teaching. New York: Prentice.

Krathwohl, D. R. 2002. A revision of Bloom's taxonomy: An overview. Theory into Practice, Vol. 41(4), 212-218.

Mulbar, Usman. 2008. Metakognisis Siswa Dalam Menyelesaikan Masalah Matematika. Makalah pendidikan. FMIPA. UNM Makasar

Munadi, Yudhi. 2008. Media Pembelajaran; Sebuah Pendekatan Baru. Ciputat : GP Press.

Nasution, S. 2008. Proses Belajar Mengajar. Jakarta: Bumi Aksara

Pintrich, P. R. 2002. The Role Of Metacognitive Knowledge In Learning, Teaching, And Assessing, Theory into Practice. Vol. 41(4), 219-225.

Rebello, N. S. \& Zollman, D. A. 2005. Trend in Physics Education Research. Department of Physics, Kansas State University, Manhattan, KS 66506-2601.

Setiawan, Agung. 2012. Metode Praktikum Dalam Pembelajaran Pengantar Fisika SMA: Studi Pada Konsep Besaran dan Satuan Tahun Ajaran 2012-2013. Jember. FKIP Univ. Jember

Severinus, Domi. 2013. Pembelajaran Fisika Seturut Hakekatnya Serta Sumbangannya Dalam Pendidikan Karakter Siswa (Seminar Nasional). Yogyakarta. FKIP Univ. Sanata Dharma Yogyakarta. LPF1311

Sibuea, A.M. 2000. Pengajaran Dengan Modul Berdasarkan Kompetensi. Medan: Jurnal 
Pengabdian Kepada Masyarakat UNIMED. Vol.6.No.22.Th.VI.

Slameto. (2003). Belajar dan Faktor-faktor yang Mempengaruhinya. Jakarta: Rineka Cipta

Schoenfeld. Ed. 1987. Conitive Science and Mathematics Education. Hillsdale.NJ: Lawrence Erlbaum Associates. Dalam http://mathforum.org/-sarah/Discussion.
Sessions/Schoenfeld.html. access in Jun $28^{\text {th }} 2013$

Simanjutak, M. P. 2012. Pengembangan Model Pembelajaran Fisika Dasar Berbasis Problem Solving untuk Meningkatkan Kemampuan Metakognisi dan Pemahaman Konsep Mahasiswa. Bandung : Universitas Pendidikan Indonesia 